\title{
Study of the sensitivity of high-strength cold-resistant shipbuilding steels to thermal cycle of arc welding
}

\author{
Pavel Layus ${ }^{1 *}$ (D), Paul Kah', Elena Khlusova ${ }^{2}$ and Victor Orlov²
}

\begin{abstract}
Background: Structure and properties of welded joints of low-alloy thermomechanically processed (09G2FB) and quenched and tempered shipbuilding steels (10XN2MD, 08XN3MD, and 12XN3MF), welded with manual metal arc welding (MMA) and submerged arc welding (SAW), were studied.

Methods: Effects of specific energy input on the microstructure, mechanical properties, and impact energy of the heat-affected zone (HAZ) have been investigated, and probable reasons for crack formation in welded joints have been found.

Results: It was found that welding heat input increase leads to a significant increase in grain size near the fusion boundary and the formation of martensite with high hardness. Therefore, the heat input is recommended to be limited to $2.5-3.5 \mathrm{~kJ} / \mathrm{mm}$ for these specific steel grades.

Conclusions: The study indicates that microalloying elements can be used to limit the grain growth when the steel is subjected to high temperatures during welding thermal cycle. Carbon content and alloying level reduction tend to increase the steel ductility and lower the HAZ toughness.
\end{abstract}

Keywords: High-strength steels, Cold-resistance, HAZ toughness, Manual metal arc welding (MMA), Submerged arc welding (SAW)

\section{Background}

In the recent decade, a wide range of high-strength coldresistant steels with high plasticity and toughness for shipbuilding were developed. Weldability of these steels is rather satisfactory, as welded parts can be used in the Arctic conditions of $-20^{\circ} \mathrm{C}$ (Akselsen et al. 2011; Gorynin et al. 2007, 2009; Layus et al. 2014). However, cold resistance of the weld joints is hard to achieve, as during welding, some irreversible structural changes occur in heat-affected zone (HAZ) caused by the influence of the welding thermal cycle (Lee et al. 2012; Khaustov 2006; Østby et al. 2012; Shin et al. 2006). These changes may result in low impact toughness in the vicinity of the fusion line and significant increase or decrease of HAZ hardness.

\footnotetext{
* Correspondence: pavel.layus@lut.fi

'Welding Technology Laboratory, Lappeenranta University of Technology, PL 20, 53851 Lappeenranta, Finland

Full list of author information is available at the end of the article
}

The microstructure of the weld joint varies continuously across different HAZ zones from the fusion line to the base metal. The variations are determined by the cooling rate, chemical composition (alloying and microalloying elements percentage), hardenability, steel production method, and, consequently, the grain size. Cooling rate $\left({ }^{\circ} \mathrm{C} / \mathrm{s}\right)$ determines the steel's microstructural characteristics on the basis of time temperature transformation (TTT) diagram. Generally, the larger the plate thickness, the slower the cooling rates are. Usually, rapid cooling is not desirable, as steel microstructure tends to convert to martensitic.

During welding, the main structural changes occur in four zones of HAZ: the first zone is the area of the grain growth or coarse-grained heat-affected zone (CGHAZ), which is immediately adjacent to the fusion line. The second and third zones are the areas of complete (FGHAZ) and partial recrystallization (ICHAZ), where heating occurs respectively above $\mathrm{A}_{\mathrm{C} 3}$ and in the inter-critical temperature range (heating between $A_{C 1}$ and $A_{C 3}$ ). The fourth region is 


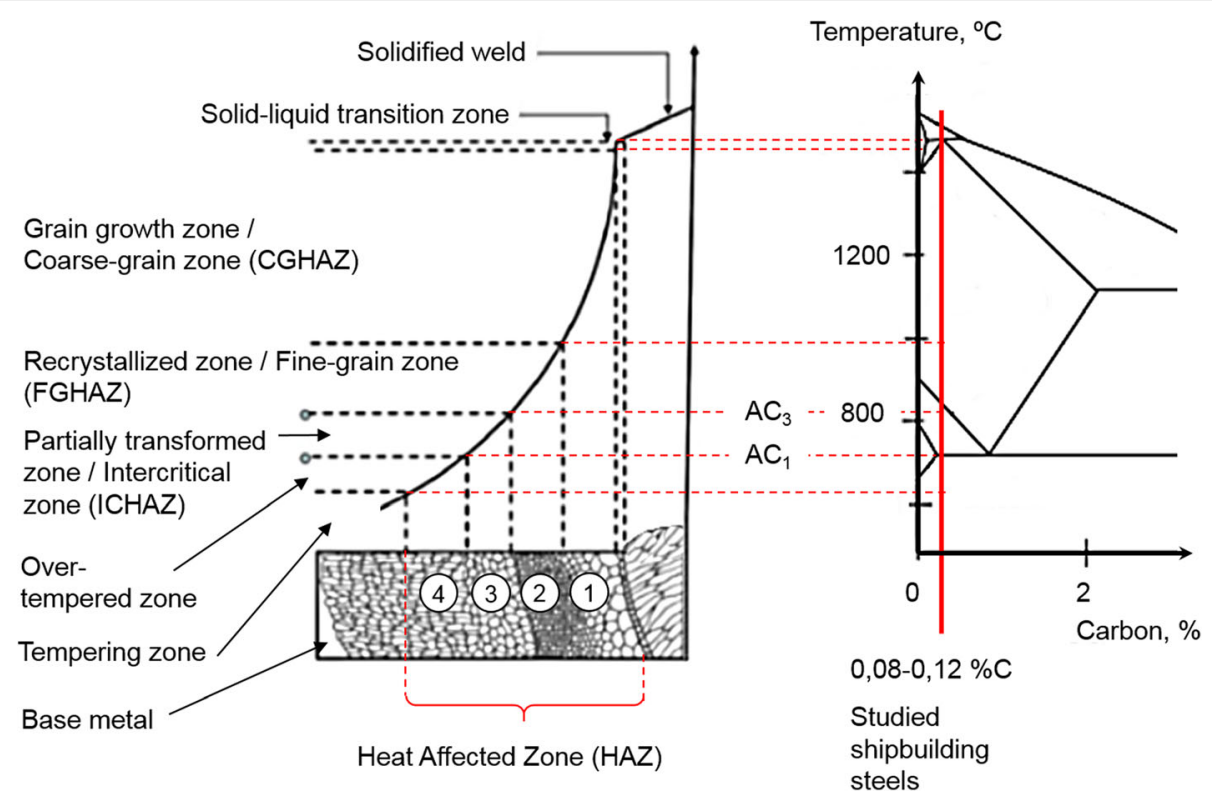

Fig. 1 Heat-affected zone structure and corresponding iron-carbon phase diagram (Grong 1997)

the tempering zone, which is heated approximately to $A_{C 1}$. The structure of HAZ and corresponding iron-carbon diagram of the studied steels is presented in Fig. 1.

In this paper, the features of the structure and properties of high-strength low-alloy and alloy steels 09G2FB, 10XN2MD, 08XN3MD, and 12XN3MF welded joints for shipbuilding industry as well as the ways to minimize the adverse effects of the thermal cycle of welding are discussed.

\section{Methods}

This research analyzes shipbuilding steel butt welds with different initial structures produced by quenching and tempering (QT) method and by thermo-mechanically controlled processing (TMCP). Depending on the steel grade, main alloying composition varies, and steels are microalloyed with $\mathrm{V}, \mathrm{Nb}$, and $\mathrm{Ti}$. The following steels were studied during this research:

- TMCP steel 09G2FB with ferrite-pearlite structure welded by submerged arc welding (SAW)

- QT steel 10XN2MD with bainite-martensite structure welded by manual metal arc welding (MMA) and SAW
- QT steels 08XN3MD and 12XN3MF with martensitic microstructure welded by MMA and SAW

Steel chemical composition is provided in Table 1. Steel production method, microstructure type, and welding parameters are given in Tables 2, 3, and 4 .

$\mathrm{Ceq}=C+\frac{\mathrm{Mn}}{6}+\frac{\mathrm{Cr}+\mathrm{Mo}+\mathrm{V}}{5}+\frac{\mathrm{Ni}+\mathrm{Cu}}{15}(\mathrm{EN} \mathrm{1011-2)}$

$P \mathrm{~cm}=C+\frac{S i}{30}+\frac{M n+C r+C u}{20}+\frac{N i}{60}+\frac{M o}{15}+\frac{V}{10}+5 B$ (Ito and Bessyo 1968)

Assessment of steel weldability was performed by carrying out MMA and SAW butt welds on the specimen with $\mathrm{K}$-shaped grooves. Welding was done parallel to the rolling direction. TMCP steels are designed to tolerate high heat inputs, as the carbon content is reduced. Therefore, welding processes with low heat inputs, such as MMA, will also show appropriate outcomes, if SAW process results are successful.

Three Charpy V-notch testing specimens were cut from each welded seam. The V-notch is located at a distance of $5 \mathrm{~mm}$ from the surface of the steel plate. The specimens were obtained from the fusion line and from 2, 5, and $20 \mathrm{~mm}$ distance from the fusion line. Charpy

Table 1 The chemical composition of analyzed steels (measured)

\begin{tabular}{|c|c|c|c|c|c|c|c|c|c|c|c|c|}
\hline Steel grade & C & $\mathrm{Si}$ & $\mathrm{Mn}$ & S & $P$ & $\mathrm{Cr}$ & $\mathrm{Ni}$ & $\mathrm{Cu}$ & $\mathrm{Mo}+\mathrm{V}+\mathrm{Nb}(+\mathrm{Ti})$ & $\mathrm{Al}$ & $\mathrm{Pcm}$ & Ceq \\
\hline 09G2FB & 0.11 & 0.30 & 1.46 & 0.005 & 0.007 & 0 & 0 & 0 & 0.09 & 0.01 & 0.20 & 0.37 \\
\hline 10XN2MD & 0.1 & 0.17 & 0.47 & 0.012 & 0.013 & 0.45 & 1.82 & 0.43 & 0.28 & 0.02 & 0.22 & 0.47 \\
\hline 08XN3MD & 0.08 & 0.32 & 0.66 & 0.002 & 0.009 & 0.89 & 2.93 & 0.67 & 0.24 & 0.03 & 0.27 & 0.66 \\
\hline $12 \mathrm{XN} 3 \mathrm{MF}$ & 0.12 & 0.26 & 0.47 & 0.011 & 0.021 & 0.94 & 2.75 & 0.12 & 0.24 & $<0.02$ & 0.27 & 0.63 \\
\hline
\end{tabular}


Table 2 Mechanical properties of studied steels (specification)

\begin{tabular}{lllll}
\hline $\begin{array}{l}\text { Steel } \\
\text { grade }\end{array}$ & $\begin{array}{l}\text { Tensile strength, } \\
\mathrm{MPa}\end{array}$ & $\begin{array}{l}\text { Yield strength, } \\
\mathrm{MPa}\end{array}$ & $\begin{array}{l}\text { Elongation, } \\
\%\end{array}$ & $\begin{array}{l}\text { Reduction } \\
\text { of area, }\end{array}$ \\
\hline 09G2FB & $\geq 550$ & $\geq 430$ & $\geq 20$ & - \\
10XN2MD & $\geq 750$ & $\geq 700$ & $\geq 19$ & $\geq 73$ \\
08XN3MD & $\geq 600$ & $\geq 550$ & $\geq 18$ & - \\
12XN3MF & $\geq 588$ & $\geq 637$ & $\geq 18$ & $\geq 55$ \\
\hline
\end{tabular}

$\mathrm{V}$-notch tests were performed at $+20,-40$, and $-60{ }^{\circ} \mathrm{C}$. For specific Charpy V-notch tests, specimens were cut in such a way that the notch was located exactly in the analyzed area of the HAZ. Charpy V-notch tests were carried out according to ISO 14556.

To assess changes in the phase composition of the weld metal caused by the thermal cycle, dilatometric studies of austenite transformation by dilatometer DIL805 (made by BÄHR Thermoanalyse) using solid and hollow cylindrical samples (10 $\mathrm{mm}$ long, $5 \mathrm{~mm}$ diameter) after heating to a maximum temperature of $1350{ }^{\circ} \mathrm{C}$ were conducted. Cooling was performed in an inert gas environment at rates of 0.5 to $100{ }^{\circ} \mathrm{C} / \mathrm{s}$. For instance, the cooling rate of $20{ }^{\circ} \mathrm{C} / \mathrm{s}$ simulates submerged arc welding of 10 -mm-thick plate, and the cooling rate of $100{ }^{\circ} \mathrm{C} / \mathrm{s}$ is typical for MMA welding thermal cycles. To identify structural changes, some samples were tempered at 600 or $640{ }^{\circ} \mathrm{C}$. These tempering temperatures are typically used to relieve stresses in the industrial manufacture of welded structures (Kaushish 2008; Lancaster 1997; Weman 2011).

Investigation of the dependence of toughness properties of the metal in the weld zone and the cooling rate after welding was performed on the equipment providing induction heating $5 \times 10 \times 55 \mathrm{~mm}$ size samples without notch at $250{ }^{\circ} \mathrm{C} / \mathrm{s}$ followed by cooling at a rate in the range of 0.1 to $300{ }^{\circ} \mathrm{C} / \mathrm{s}$ (in different environments) to study the effects of different types of welding with different heat input. The dwell time during the tempering of the specimens to a temperature of 600 and $640{ }^{\circ} \mathrm{C}$ was $4 \mathrm{~min}$. The value of the toughness in the simulated weld zone was compared with the properties of the base metal at the selected test temperatures $\left(-20\right.$ and $\left.-40{ }^{\circ} \mathrm{C}\right)$.

Tensile tests were carried out using Gleeble-3800 on specimens of $20 \mathrm{~mm}$ length with specimen working diameter of $8 \mathrm{~mm}$ according to ISO 6892 standard. To ensure the minimum temperature, the gradient along the length of the sample used special grippers with the internal track. Temperature control was carried out using platinum-rhodium thermocouple welded precisely to the specimen center. Experiments were conducted in a vacuum, which level was $10^{-5} \mathrm{~Pa}$.

For steel 10XN2MD, thermopower loading modes were performed:

a) Heating to a temperature of $600{ }^{\circ} \mathrm{C}$, holding $10 \mathrm{~min}$, and tensile strain to failure at a rate of $5.5 \times 10^{-6} \mathrm{~s}^{-1}$ to simulate the effects of post-weld tempering of the base metal

b) Heating to a temperature of $1350{ }^{\circ} \mathrm{C}$, holding for $3 \mathrm{~s}$, and cooling at a rate of $100{ }^{\circ} \mathrm{C} / \mathrm{s}-$ simulated thermal cycle of welding at the most "hard" embodiment-and then heated to a temperature $600{ }^{\circ} \mathrm{C}$, holding for $10 \mathrm{~min}$, and tensile strain to failure at a rate of $5.5 \times 10^{-6} \mathrm{~s}^{-1}$ to simulate the effects of welding after the tempering in the coarse-grained area of the HAZ.

The rate of $5.5 \times 10^{-6} \mathrm{~s}^{-1}$, the expected rate of deformation during welding, stresses relaxation at high tempering (Michailov et al. 2016). Comparative assessment of the tensile strengths was determined by the elongation of the samples after the test. Microhardness measurements were made for all welding using AFFRI DM-8 testing equipment in different zones of the heataffected zone of the welded joint with a load of $0.1 \mathrm{kgf}$.

The structure of the metal was investigated by optical microscopy and scanning electron microscopy. Metallographic examination of samples was performed on an inverted microscope Axiovert 25CA or light metallographic microscope AxioObserverA1M digital image

Table 3 Steel thickness, production method, and welding parameters

\begin{tabular}{|c|c|c|c|c|c|c|}
\hline Steel grade & $\begin{array}{l}\text { Plate thickness, } \\
\mathrm{mm}\end{array}$ & $\begin{array}{l}\text { Steel production } \\
\text { method }\end{array}$ & Welding process & Welding consumables & $\begin{array}{l}\text { Heat input during } \\
\text { welding, } \mathrm{kJ} / \mathrm{mm}\end{array}$ & $\begin{array}{l}\text { HAZ width } \\
\mathrm{mm}\end{array}$ \\
\hline \multirow[t]{2}{*}{ 09G2FB } & \multirow[t]{2}{*}{50} & \multirow[t]{2}{*}{ TMCP } & \multirow{2}{*}{$\begin{array}{l}\text { Multipass submerged } \\
\text { arc welding }\end{array}$} & \multirow{2}{*}{$\begin{array}{l}\text { Welding electrode SFA/AWS } \\
\text { ER120S-1, with flux 48AF-50 }\end{array}$} & 1.5 & $2-2.5$ \\
\hline & & & & & 5.0 & $6-7$ \\
\hline \multirow[t]{2}{*}{ 10XN2MD } & \multirow[t]{2}{*}{24} & \multirow[t]{2}{*}{ QT } & $\begin{array}{l}\text { Manual metal arc } \\
\text { welding }\end{array}$ & $\mathrm{E} 504$ 2NiB12H5, Ø4 mm & Not measured & 1.8 \\
\hline & & & $\begin{array}{l}\text { Multipass submerged } \\
\text { arc welding }\end{array}$ & $\begin{array}{l}\text { Welding electrode Sv-08GSMT, } \\
\varnothing 4 \mathrm{~mm} \text {, with flux AN-42 }\end{array}$ & 5.2 & 4.3 \\
\hline 08XN3MD & 35 & & $\begin{array}{l}\text { Multipass submerged } \\
\text { arc welding }\end{array}$ & $\begin{array}{l}\text { Welding electrode 08GNMDTA, } \\
\varnothing 4 \mathrm{~mm} \text {, with flux 48AF-60 }\end{array}$ & 5.5 & 4.4 \\
\hline $12 X N 3 M F$ & 25 & & Manual metal arc welding & $\mathrm{E} 504$ 2NiB12H5, Ø4 mm & Not measured & 5.4 \\
\hline
\end{tabular}


Table 4 Welding consumable chemical composition (specification)

\begin{tabular}{|c|c|c|c|c|c|c|c|c|c|}
\hline \multicolumn{10}{|c|}{ Welding electrode SFA/AWS ER120S-1 deposited weld metal, wt\% } \\
\hline C & $\mathrm{Si}$ & $\mathrm{Mn}$ & S & $P$ & $\mathrm{Cr}$ & $\mathrm{Ni}$ & Mo & $\mathrm{N}_{2}$ & $\mathrm{O}_{2}$ \\
\hline$\leq 0.05$ & $\leq 0.20$ & $1.3-1.6$ & $\leq 0.012$ & $\leq 0.015$ & $\leq 0.30$ & $2.4-2.8$ & $0.2-0.3$ & $0.05-0.12$ & $\leq 0.005$ \\
\hline \multicolumn{10}{|c|}{ Welding electrode E50 4 2NiB12H5 (EN 499:2009) deposited weld metal, wt\% } \\
\hline C & $\mathrm{Si}$ & $\mathrm{Mn}$ & $\mathrm{S}$ & $\mathrm{P}$ & $\mathrm{Ni}$ & & & & \\
\hline$\leq 0.12$ & $0.15-0.35$ & $0.8-1.2$ & $\leq 0.025$ & $\leq 0.030$ & $1.65-2.1$ & & & & \\
\hline \multicolumn{10}{|c|}{ Welding electrode Sv-08GSMT (GOST 2246-70) deposited weld metal, wt\% } \\
\hline C & $\mathrm{Mn}$ & $\mathrm{Si}$ & S & $P$ & $\mathrm{Ni}$ & & & & \\
\hline$\leq 0.10$ & $1.4-1.8$ & $0.6-0.9$ & $\leq 0.03$ & $\leq 0.03$ & $0.8-1.2$ & & & & \\
\hline \multicolumn{10}{|c|}{ Welding electrode 08GNMDTA (GOST 2246-70) deposited weld metal, wt\% } \\
\hline C & $\mathrm{Mn}$ & $\mathrm{Si}$ & S & $P$ & $\mathrm{Ni}$ & $\mathrm{Ti}$ & Mo & $\mathrm{Cu}$ & \\
\hline$\leq 0.10$ & $1.4-1.8$ & $0.2-0.4$ & $\leq 0.03$ & $\leq 0.03$ & $0.8-1.2$ & $0.07-0.10$ & $0.15-0.30$ & $0.40-0.60$ & \\
\hline \multicolumn{10}{|c|}{ Welding flux 48AF-60, wt\% } \\
\hline $\mathrm{SiO}_{2}$ & $\mathrm{MgO}$ & $\mathrm{CaF}_{2}$ & $\mathrm{Al}_{2} \mathrm{O}_{3}$ & & & & & & \\
\hline $12-21$ & $7-16$ & $9-18$ & $36-46$ & & & & & & \\
\hline \multicolumn{10}{|c|}{ Welding flux AN-42, wt\% } \\
\hline $\mathrm{SiO}_{2}$ & $\mathrm{CaO}$ & $\mathrm{MnO}$ & $\mathrm{Al}_{2} \mathrm{O}_{3}$ & $\mathrm{CaF}_{2}$ & $\mathrm{Fe}_{2} \mathrm{O}_{3}$ & $\mathrm{~S}$ & $P$ & & \\
\hline $30-34$ & $12-18$ & $14-19$ & $13-18$ & $9-18$ & $\leq 1$ & $\leq 0.06$ & $\leq 0.1$ & & \\
\hline
\end{tabular}

analyzer after etching in a $4 \%$ alcohol solution of nitric acid. Analysis of the fracture surface of the samples was performed using a scanning electron microscope EM 535.

Welding of cold-resistant steel 10XN2MD was performed with a change in heat input $(5,3.3$, and $2.5 \mathrm{~kJ} / \mathrm{mm})$ in a single pass, with the focus of the beam on the surface. The welding speed varied from 10 to $20 \mathrm{~mm} / \mathrm{s}$.

\section{Results and discussion}

Calculated cooling time and martensite start temperature Values of $t_{8 / 5}, M_{s}, A_{c 1}, A_{c 3}$, and highest hardness were calculated according to the methods described below.

\section{Cooling time}

Welding cooling time is usually described as $t_{8 / 5}$, which is the cooling time from 800 to $500{ }^{\circ} \mathrm{C}$, as these temperatures normally correspond to the recrystallization temperatures of steels. Cooling time can be either measured with thermocouples or calculated theoretically using the following formula (EN 1011-2):

$$
t_{8 / 5}=\left(6700-5 T_{p}\right) \times Q \times\left(\frac{1}{500-T_{p}}-\frac{1}{800-T_{p}}\right) \times F
$$

where $t_{8 / 5}$ is the cooling time $(\mathrm{s}), T p$ is preheat temperature $\left({ }^{\circ} \mathrm{C}\right), Q$ is the heat input $(\mathrm{kJ} / \mathrm{mm})$, and $F$ is the proper shape factor, which depends on the weld seam shape, which is 1 for a butt weld.

\section{Martensite start temperature}

This toughness reduction is a result of a martensite/ austenite phase, which often forms during reheating and subsequent cooling of the HAZ. When the coarsegrained microstructure is reheated to the two-phase region of the phase diagram, islands of austenite are formed at grain boundaries and near previous austenite boundaries. The formed austenite has a high-alloy content, which reduces both the martensite start (Ms) and finish (Mf) temperature, and the ability to form perlite and ferrite at high cooling rates. Because of the low Ms and Mf temperatures, the austenite islands will form a mixture of brittle martensite and retained austenite. The decreasing effect of the alloy elements on the Ms temperature can be seen from the equation (Hansen 2012):

$$
\begin{aligned}
M_{s}=539 & -423(\mathrm{wt} \% \mathrm{C})-30.4(\mathrm{wt} \% \mathrm{Mn})+17.7(\mathrm{wt} \% \mathrm{Ni}) \\
& +12.1(\mathrm{wt} \% \mathrm{Cr})+7.8(\mathrm{wt} \% \mathrm{Mo})
\end{aligned}
$$

The transformation temperatures, designated Ac1 and Ac3, can be found experimentally from a dilatometer curve. These temperatures can also be determined theoretically using the equations below (Odessky 2006):

$$
\begin{array}{r}
A_{c 1}=723-10.7(\mathrm{wt} \% \mathrm{Mn})-16.9(\mathrm{wt} \% \mathrm{Ni})+29.1(\mathrm{wt} \% \mathrm{Si}) \\
+16.9(\mathrm{wt} \% \mathrm{Cr})+290(\mathrm{wt} \% \mathrm{As})+6.38(\mathrm{wt} \% \mathrm{~W}) \\
A_{c 3}=910-203(\mathrm{wt} \% \mathrm{C}) 1 / 2-15.2(\mathrm{wt} \% \mathrm{Ni})+44.7(\mathrm{wt} \% \mathrm{Si}) \\
+104(\mathrm{wt} \% \mathrm{~V})+31.5(\mathrm{wt} \% \mathrm{Mo})+13.1(\mathrm{wt} \% \mathrm{~W})
\end{array}
$$

One of the most commonly used criteria to evaluate the quality of the weld is the hardness measurement. 
Table 5 Calculated values for the studied steels

\begin{tabular}{|c|c|c|c|c|c|c|c|c|}
\hline \multirow{2}{*}{$\begin{array}{l}\text { Heat input } \\
\text { during welding }\end{array}$} & \multicolumn{4}{|l|}{$\mathrm{t}_{8 / 5}, \mathrm{~s}$} & \multirow[t]{2}{*}{$\mathrm{Ms},{ }^{\circ} \mathrm{C}$} & \multirow[t]{2}{*}{$\mathrm{Ac}_{1},{ }^{\circ} \mathrm{C}$} & \multirow[t]{2}{*}{$\mathrm{AC}_{3},{ }^{\circ} \mathrm{C}$} & \multirow[t]{2}{*}{$\mathrm{Hv}$} \\
\hline & $1.5 \mathrm{~kJ} / \mathrm{mm}$ & $5 \mathrm{~kJ} / \mathrm{mm}$ & $5.2 \mathrm{~kJ} / \mathrm{mm}$ & $5.5 \mathrm{~kJ} / \mathrm{mm}$ & & & & \\
\hline $09 \mathrm{G} 2 \mathrm{FB}$ & 8 & 26 & - & - & 448 & 716 & 865 & 329 \\
\hline 10XN2MD & - & - & 27 & - & 520 & 700 & 855 & 307 \\
\hline 08XN3MD & - & - & - & 29 & 548 & 691 & 847 & 354 \\
\hline 12XN3MF & - & - & - & - & 534 & 695 & 834 & 375 \\
\hline
\end{tabular}

Hardness is measured experimentally, and the following formula can also estimate the maximum hardness of the HAZ for HSLA steels:

$$
\begin{aligned}
H V=90 & +1050(w \mathrm{t} \% \mathrm{C})+47(\mathrm{wt} \% \mathrm{Si})+75(\mathrm{wt} \% \mathrm{Mn}) \\
& +30(w \mathrm{t} \% \mathrm{Ni})+31(w \mathrm{t} \% \mathrm{Cr})
\end{aligned}
$$

This equation states that carbon content governs the hardness values of the HAZ. From practical observations, it was noted that if the hardness of HAZ exceeds the hardness of the base metal by more than 20-30\%, the probability of cold cracking rises significantly, impact strength decreases, and inhomogeneity of the weld becomes high.

For the studied steels, the calculation of predicted values is listed in Table 5.

\section{Features of structures and properties of the SAW weld} joints of TMCP low-alloy shipbuilding 09G2FB steel

The evaluation was conducted on the weldability of butt weld samples with K-joint edges of the 50-mm-thick 09G2FB steel plate fabricated by TMCP.

Analysis of microstructure after welding with a low heat input of $1.5 \mathrm{~kJ} / \mathrm{mm}$ showed the formation of lower bainite in the CGHAZ, with a grain size of $44-88 \mu \mathrm{m}$ (Fig. 2c), which corresponds to grain size 4-6 according to ISO 643:2003. After welding with high heat input $(5 \mathrm{~kJ} / \mathrm{mm})$ on the boundary of fusion line, a substantial grain growth (up to $150 \mu \mathrm{m}$, which corresponds to grain size 2-3 according to ISO 643:2003) near the fusion line and the formation of ferrite of irregular shape on the boundaries of austenitic grains is observed (Fig. 2b). This results in an increase of HAZ length from 2-2.5 to 6$7 \mathrm{~mm}$ (Table 3) with the increase in heat input.

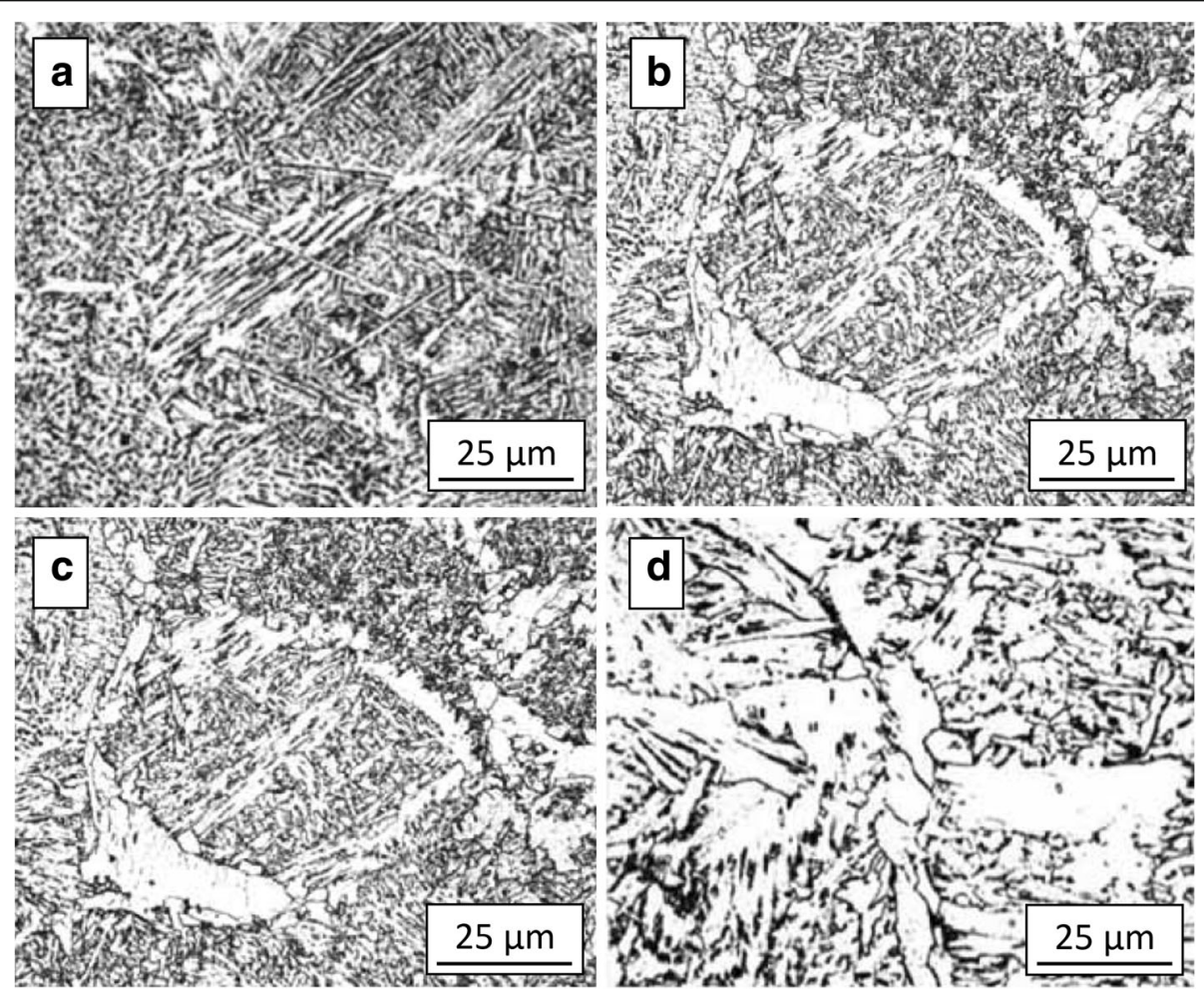

Fig. 2 The microstructure of 09G2FB in various regions of HAZ. a Fusion line with welding heat input $1.5 \mathrm{~kJ} / \mathrm{mm}$. b Fusion line with welding heat input $5 \mathrm{~kJ} / \mathrm{mm}$. c CGHAZ region with welding heat input $1.5 \mathrm{~kJ} / \mathrm{mm}$. d CGHAZ region with welding heat input $5 \mathrm{~kJ} / \mathrm{mm}$ 
Table 6 Hardness (mean value) in various regions of HAZ of welded joint of steel 09G2FB

\begin{tabular}{lll}
\hline Test location & $\begin{array}{l}\text { Heat input of } \\
1.5 \mathrm{~kJ} / \mathrm{mm}\end{array}$ & $\begin{array}{l}\text { Heat input of } \\
5 \mathrm{~kJ} / \mathrm{mm}\end{array}$ \\
\hline Fusion line & 284 & 244 \\
$2 \mathrm{~mm}$ from the fusion line & 274 & 208 \\
$5 \mathrm{~mm}$ from the fusion line & - & 234 \\
Base metal & 236 & \\
\hline
\end{tabular}

The microstructure of HAZ at $2 \mathrm{~mm}$ from the fusion line is lower bainite, and microstructure of HAZ at $5 \mathrm{~mm}$ from the fusion line is a mixture of ferrite and lower bainite. This microstructure causes an increase of hardness and decrease in impact energy values.

As a result of the reduction in the cooling rate, an unfavorable structure of coarse-grained upper bainite with free ferrite precipitates along its boundaries is formed with an increase in the heat input from 1.5 to $5 \mathrm{~kJ} / \mathrm{mm}$ (Fig. 2d), which has low impact values at $-40{ }^{\circ} \mathrm{C}$. Calculated $\mathrm{t}_{8 / 5}$ cooling times were $8 \mathrm{~s}$ for $1.5 \mathrm{~kJ} / \mathrm{mm}$ and $26 \mathrm{~s}$ for $5 \mathrm{KJ} / \mathrm{mm}$ heat input. Microhardness and impact toughness are presented in Tables 6, 7, and 8 .

Impact test values are higher when welding with lower heat input, as it can be seen from Table 8. The impact test value on the fusion line for $5 \mathrm{~kJ} / \mathrm{mm}$ heat input is rather low $-33 \mathrm{~J} / \mathrm{cm}^{2}$.

TMCP procedure allows keeping desirable HAZ microstructure when steel is heated up to the $A_{c 3}$ point, because of the increased content of alloying elements. However, this approach is not limiting significant grain growth at the higher temperatures. Therefore, welding heat input for welding this grade of TMCP steel has to confine itself to $2.5-3.5 \mathrm{~kJ} / \mathrm{mm}$ to guarantee acceptable impact toughness in the fusion line and avoid excessive grain growth in the HAZ (Schastlivtsev et al. 2013).

Increasing the heat input leads to the growth of austenite grains and decrease the cooling rate as compared with a low heat input welding. As a result of the conversion in $\gamma \rightarrow \alpha$, low-carbon low-alloy steel begins with a selection of free ferrite. Therefore, increased carbon content results in unconverted austenite, and the border is formed by fusing an unfavorable structure of coarse bainite with the secretions of free ferrite at its

Table 7 Mechanical properties of welded joints of steel 09G2FB

\begin{tabular}{lll}
\hline & Heat input & Heat input \\
& $1.5 \mathrm{~kJ} / \mathrm{mm}$ & $5 \mathrm{~kJ} / \mathrm{mm}$ \\
\hline Tensile strength, Mpa & 541 & 555 \\
Yield strength, MPa & 443 & 449 \\
Relative elongation, \% & 21.5 & 23.8 \\
\hline
\end{tabular}

Table 8 Impact test values at $-40{ }^{\circ} \mathrm{C}$ of welded joints of steel 09G2FB $\left(\mathrm{J} / \mathrm{cm}^{2}\right)$

\begin{tabular}{lll}
\hline & $\begin{array}{l}\text { Heat input of } \\
1.5 \mathrm{~kJ} / \mathrm{mm}\end{array}$ & $\begin{array}{l}\text { Heat input of } \\
5 \mathrm{~kJ} / \mathrm{mm}\end{array}$ \\
\hline Fusion line & 83.4 & 33 \\
$2 \mathrm{~mm}$ from the fusion line & 32 & 27.8 \\
$5 \mathrm{~mm}$ from the fusion line & 94 & 35.2 \\
Base metal & 121.3 & \\
\hline
\end{tabular}

boundaries, as can be seen in Fig. 2, having low values of impact energy.

Features of structures and properties of the weld joints of QT alloying shipbuilding steel (by MMA and SAW welding)

QT steels MMA and SAW welded butt welds were made of chrome-nickel-molybdenum steel 10XN2MD, bainitemartensite structure steel 08XN3MD, and steel of the martensitic grade $12 \mathrm{XN} 3 \mathrm{MF}$.

\section{Arc welding}

Comparative studies of HAZ microstructure and properties of MMA welded steel grades 10XN2MD, 08XN3MD, and 12XN3MF showed that with an increase in the level of carbon and alloying elements, the width of HAZ increases from 1.8 to $5.4 \mathrm{~mm}$, as stated in Table 3 .

The grain size in the first section of the HAZ (Fig. 1) has a coarse-grained martensitic structure, which grains are 1.5-2 times larger in steel 12XN3MF than in steel $10 \mathrm{XN} 2 \mathrm{MD}$, where the grain size does not exceed to $110 \mu \mathrm{m}$, and the structure is predominantly bainitic, which determines the decrease in microhardness in section 1 of the HAZ in steel 10XN2MD and promotes increase in toughness. The formation of a mainly bainitic structure as a result of a reduction in the carbon content of high-strength chromium-nickel-molybdenum steel contributes to a $25 \%$ hardness decrease in the HAZ and an increase in toughness (Table 9).

Section 2 of the HAZ of 12XN3MF consists mostly of the martensitic structure, which is refined as it moves away from the fusion boundary and converts into the bainitic-martensitic structure of section 3. 10XN2MD steel does not have a clear boundary between sections 2 and 3, which consist of a dispersed bainitic-ferritic structure.

Table 9 Hardness of HAZ in welds by MMA and SAW

\begin{tabular}{llllll}
\hline & Steel grade & \multicolumn{4}{l}{ Distance from the fusion line, $\mathrm{mm}$} \\
\cline { 3 - 6 } & & 1 & 2 & 3 & 4 \\
\hline MMA & 12XN3MF & 298 & 280 & 260 & 250 \\
& 10XN2MD & 235 & 238 & 217 & 200 \\
\multirow{3}{*}{ SAW } & 10XN2MD & 235 & 222 & 209 & 187 \\
& 08XN3MD & 183 & 180 & 175 & 172 \\
\hline
\end{tabular}


Analysis of HAZ of submerged arc welded 10XN2MD grade showed that the microhardness does not exceed to $235 \mathrm{Hv}$ and the microhardness values gradually decrease from the fusion line to the base metal ranging from 235 to $187 \mathrm{Hv}$ (Table 9).

Study of SAW welded steel grades 10XN2MD and 08XN3MD show that the HAZ section 1 consists of a coarse-grained bainite structure with ferrite sections along the boundaries and sections 2 and 3 are predominantly a bainitic-ferrite mixture in which the grain size decreases with distance from the fusion line. Section 4 of the HAZ has a larger-grained bainiticferrite structure corresponding to the structure of the parent metal, with carbides along the grain boundaries. As the transition to the base metal structure happens, the carbides that included in the boundaries disappear.

Steel 08XN3MD with a high content of chromium and nickel, but with a lower carbon content (0.08 vs. $0.10 \%)$, was welded by SAW. The microhardness of the HAZ is the lowest: 171-183 Hv, i.e., $28 \%$ lower than steel 10XN2MD. Steel 10XN2MD has lower Pcm values $(0.23 \%)$ because of the lower content of the alloying elements. The maximum hardness is observed on the sections of the HAZ 1 (coarse-grained) and 2 (finegrained) adjacent to the weld metal, having an acicular structure. The impact strength of the welded joint a test temperature of $-40{ }^{\circ} \mathrm{C}$ has values of $183-171$ (steel 08XN3MD) and 235-187 J/ $\mathrm{cm}^{2}$ (steel 10XN2MD).

Thus, a reduction in the carbon content, amount of alloying elements, and formation of a bainitic structure in the steel of the nickel-nickel-molybdenum composition result in an increase in the toughness level and a reduction of the HAZ hardness in both MMA and SAW welding. It was observed that a lower carbon content in the steel has a stronger influence on the toughness of the welded joint, then an increase in the alloying elements percentage.

By increasing the content of carbon and alloying elements in steel 12XN3MDF, the HAZ width increases and has a maximum hardness of HAZ region with acicular structure. Formation of mainly bainite structure by reducing the carbon content of chrome-nickelmolybdenum steel 10XN2MD helps to reduce the HAZ hardness of welded joints by $25 \%$ and also to increase the ductility to almost at the base metal level.

For welded high-strength steel structures, afterwelding tempering is often required to remove residual stresses. However, after tempering of the welded joints, which are made of high-strength welded chrome-nickelmolybdenum steels, the cracking localized in the HAZ or directly along the weld line is observed.

When testing a simulated metal weld zone (HAZ region) on samples with a sharp notch at a test temperature of $+20,+40$ and $-60{ }^{\circ} \mathrm{C}$, it was found that the maximum level of impact strength at all temperatures corresponds to a cooling rate of $6{ }^{\circ} \mathrm{C} / \mathrm{s}$. After tempering the specimens, hardness increases and the toughness is significantly reduced over the entire range of cooling rates (Fig. 3). It can be associated with the pinning of dislocations during tempering segregations that usually results in increased hardness and brittle behavior.

To investigate the possible welding residual stress, the structure and nature influence of the fracture studies were performed (Fig. 4c, f). During the study, the following parameter was used: the base metal and HAZ coarse-grained region after heating to $600{ }^{\circ} \mathrm{C}$ and slow strain rate tension with $5.5 \times 10^{-6} \mathrm{~s}^{-1}$.

Tempering without deformation slightly changes the structure of the base metal and the coarse-grained region. After the combined effects of temperature and slow
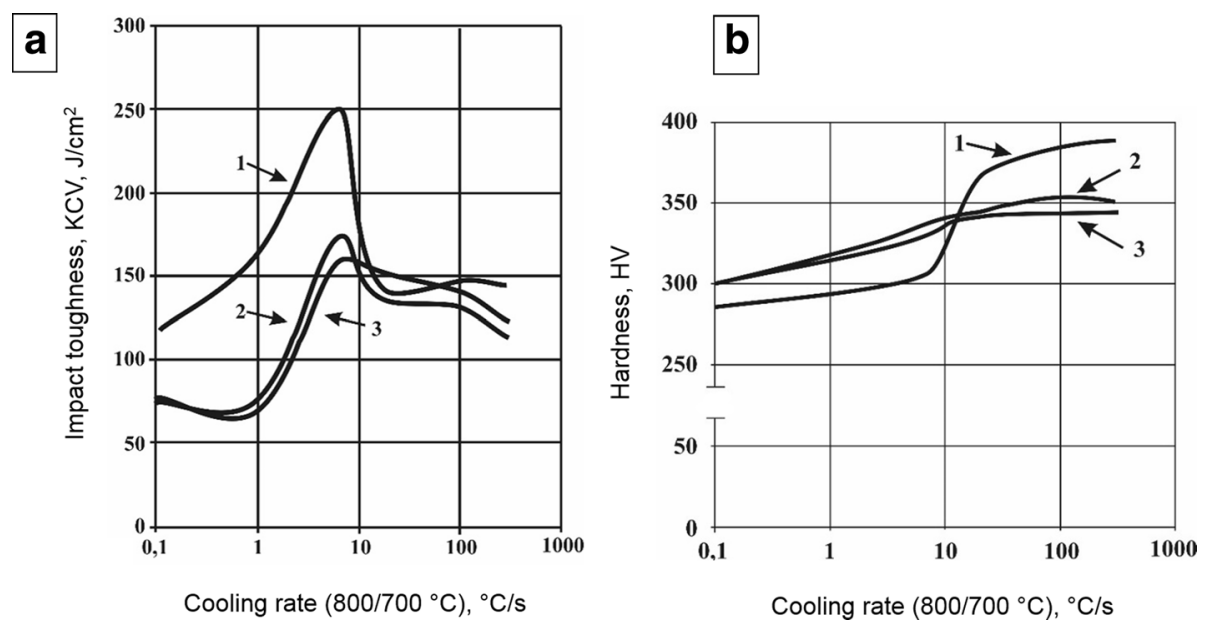

Fig. 3 Change of hardness (a) and toughness (b) in the HAZ region versus temperature test samples of steel $10 \mathrm{XN} 3 \mathrm{MD}$ at different cooling rates after welding before and after tempering at 600 (2) and $640{ }^{\circ} \mathrm{C}(3)$, as well as after simulation of heating (1) 


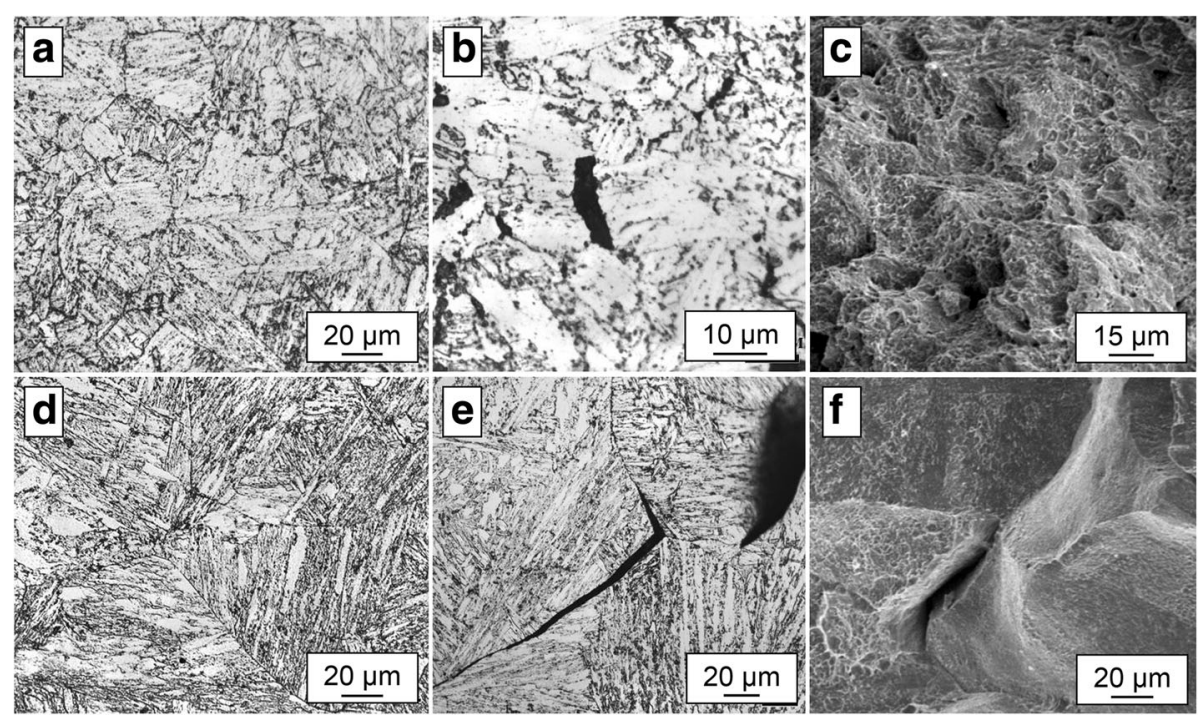

Fig. 4 The structure $(\mathbf{a}, \mathbf{b}, \mathbf{d}, \mathbf{e})$ and fracture $(\mathbf{c}, \mathbf{f})$ of the base metal 10XN3MD after tempering $600{ }^{\circ} \mathrm{C}(\mathbf{a})$ and simulated on Gleeble-3800 coarse-grained region of the $\mathrm{HAZ}$ and of steel $10 \mathrm{XN} 3 \mathrm{MDF}$ after heating to $600^{\circ} \mathrm{C}$ and tempering $1350^{\circ} \mathrm{C}(\mathbf{g})$ and after deformation at a speed $5.5 \times 10^{-6} \mathrm{~s}^{-1}$ at a temperature of $600^{\circ} \mathrm{C}(\mathbf{b}, \mathbf{c}, \mathbf{e}, \mathbf{f})$, the base metal $(\mathbf{b}, \mathbf{c})$, and the coarse-grained region $(\mathbf{d}, \mathbf{f})$

deformation, the steel 10XN3MD structure completely loses its original martensitic-bainitic structure, which turns into a ferrite-carbide mixture of ferrite grains, elongated in the direction of the load (Fig. 4b). Most of the ferrite grains have a size of $12-15 \mu \mathrm{m}$, but there is a small grain of 3-5 $\mu \mathrm{m}$ size. Along with that, individual coarse grains with a size of about $100 \mu \mathrm{m}$ are observed in the structure. They result from the recrystallization development in situ (Fig. 4). The time to failure is $23,070 \mathrm{~s}$, and elongation is $14 \%$ (see Table 10).

The structure of the coarse-grained region after the combined effects of temperature and slow deformation is tempered coarse-grained martensite with the cracks along the boundaries and triple junctions of grain (Fig. 4e). Time to failure is reduced to $4970 \mathrm{~s}$, and elongation is reduced to $1 \%$.

The applied strain causes the fracture of the grain boundary sliding mechanism, resulting in stress concentration at triple junctions and the formation of the wedge-shaped cracks. It is obvious that the accumulation of interstitial atoms (presumably carbon) on the coarse-grained boundaries at the selected tempering temperature makes it difficult to slide, facilitating the cracks and brittle fracture appearance. Longer tempering may promote the formation of carbides at the grain

Table 10 Test results after deformation by stretching at a temperature of $600{ }^{\circ} \mathrm{C}$ of steel $10 \mathrm{XN} 3 \mathrm{MD}$

\begin{tabular}{lll}
\hline & $\begin{array}{l}\text { Time before } \\
\text { failure, } \mathrm{s}\end{array}$ & $\begin{array}{l}\text { Elongation for } \\
15 \mathrm{~mm} \text { base, \% }\end{array}$ \\
\hline Base metal & 23,070 & 14 \\
Imitation of the HAZ region & 4970 & 1 \\
\hline
\end{tabular}

boundaries, cavitation, and also lead to the fracture. In this regard, if weld joints tempering is required, its modes should be optimized taking into account the effects of possible metal deformation reduction.

\section{Conclusions}

1. The structure of low-alloy shipbuilding steel is not resistant to high-temperature stress. A complex microalloying should be used to prevent grain growth at high-temperature heating (above $1100{ }^{\circ} \mathrm{C}$ ) and the risk of reducing the impact energy on the boundary fusion.

2. For the alloying shipbuilding steel, welding heat input increase leads to a significant increase in grain near the fusion boundary and the formation of martensite with high hardness due to increased stability of the austenite. Reduction of the carbon content and alloying level increases the ductility and lowers the HAZ toughness. Tempering weld alloy steels lead to a decrease in toughness as compared with the hardened condition.

3. The combined effect of heating to temperatures of tempering and slow stretching deformation to fracture, simulating the effect of residual stresses on the coarse-grained portion of the HAZ near the fusion line, causes the reduction of plasticity and the formation of micro-cracks in the triple grain junctions and characteristic for the development of intergranular slip in the short-term creep flow. The sharp decline in the deformation of the metal at the weld line can cause cracks in welded joints of low-carbon alloy steel with the post-weld vacation. 


\section{Abbreviations}

CGHAZ: Coarse-grained heat-affected zone; FGHAZ: Fine-grained (complete recrystallized) heat-affected zone; HAZ: Heat-affected zone; HSLA: Highstrength low-alloy steel; ICHAZ: Intercritical (partial recrystallization) heataffected zone; MMA: Manual metal arc welding; QT: Quenched and tempered; SAW: Submerged arc welding; TMCP: Thermo-mechanically controlled processing; TाT: Time temperature transformation diagram

\section{Acknowledgements}

Not applicable.

\section{Funding}

Not applicable.

\section{Availability of data and materials}

The experimental and numerical data is fully given in the paper, and there is no other data used for this study.

\section{Authors' contributions}

$\mathrm{PL}$ wrote and formatted the work for the submission, performed the calculations, wrote the discussion part, and made an analysis and an interpretation of the presented experimental results. PK gave valuable advices during the study and critically revised the work. Also, he contributed to the discussion part. EK and VO contributed to the study design and supervised the experimental work. Also, they provided their expert opinion on the microstructure characterization issues. All authors read and approved the final manuscript.

\section{Authors' information}

Not applicable.

\section{Competing interests}

The authors declare that they have no competing interests.

\section{Publisher's Note}

Springer Nature remains neutral with regard to jurisdictional claims in published maps and institutional affiliations.

\section{Author details}

${ }^{1}$ Welding Technology Laboratory, Lappeenranta University of Technology, PL 20, 53851 Lappeenranta, Finland. National Research Centre "Kurchatov Institute" Federal State Unitary Enterprise Academician I.V. Gorynin Central Research Institute of Structural Materials Prometey, Saint-Petersburg, Russia.

Received: 12 September 2017 Accepted: 22 January 2018

Published online: 05 February 2018

\section{References}

Akselsen, OM, Østby, E, Thaulow, C. (2011). Low temperature toughness in SA welding of $420 \mathrm{MPa}$ steel, in: The Twenty-first International Offshore and Polar Engineering Conference, International Society of Offshore and Polar Engineers, pp. 414-420.

Gorynin, I, Rybin, V, Malyshevskii, V, Khlusova, E. (2007). Alloying principles, phase transformations, structure and properties of low-temperature weldable shipbuilding steels. Metal Science and Heat Treatment, 49(1-2), 3-9.

Gorynin, Y, Rybin, V, Malyshevskii, V. (2009). Cold resistant steels for the Arctic shelf (in Russian). Voprosy Materialovedeniya Journal, 3(59), 108-126.

Grong, O (1997). Metallurgical modelling of welding, (2nd ed., ). Maney Publishing. p. 677, ISBN:9781861250360.

Hansen, K (2012) Phase transformation study of X70 steel by EBSD during in situ heating and quenching.

Ito, Y, \& Bessyo, K (1968). Weldability formula of high strength steels related to heat affected zone cracking. IIW Doc. IX-576-68, International Institute of Welding.

Kaushish, J (2008). Manufacturing processes. New Deli: PHI Learning Pvt. Ltd.

Khaustov, A. (2006). New cold-resistant steels for shipbuilding (in Russian). Sudostroenie, 4(767), 57-58.

Lancaster, JF. (1997). Handbook of structural welding: processes, materials and methods used in the welding of major structures, pipelines and process plant. Abington Publishing. p. 436, ISBN:978-1-85573-343-5.
Layus, P, Kah, P, Martikainen, J, Gezha, V, Bishokov, R. (2014). Multi-wire SAW of $640 \mathrm{MPa}$ Arctic shipbuilding steel plates. The International Journal of Advanced Manufacturing Technology, 75(5-8), 771-782.

Lee, C, Shin, H, Park, K. (2012). Evaluation of high strength TMCP steel weld for use in cold regions. Journal of Constructional Steel Research, 74, 134-139.

Michailov, V, Karkhin, V, Petrov, P (2016). Principles of welding. Saint-Petersburg: St. Petersburg Polytechnic University.

Odessky, P, Smirnov L A, Kulik, DV (2006) Microalloying of steels for the north and unique metal structures (in Russian). Intermet Engineering, p. 176, ISBN 589594-140-0.

Østby, E, Kolstad, G, Akselsen, O (2012). Comparison of fracture toughness in real weld and thermally simulated CGHAZ of a 420MPa rolled plate, (pp. 315-322). Mountain View.

Schastlivtsev, VM, Tabatchikova, TI, Yakovleva, IL, Klyueva, SY, Kruglova, AA, Khlusova, El, Orlov, W. (2013). Effect of austenite-decomposition temperature on bainite morphology and properties of low-carbon steel after thermomechanical treatment. Physics of Metals and Metallography, 114(5), 419-429.

Shin, Y, Kang, S, Lee, H. (2006). Fracture characteristics of TMCP and QT steel weldments with respect to crack length. Materials Science and Engineering, 434(1-2), 365-371.

Weman, K (2011). Welding processes handbook, 2nd ed., Woodhead Publishing, p. 280, ISBN:9780857095183

\section{Submit your manuscript to a SpringerOpen ${ }^{\circ}$ journal and benefit from:}

- Convenient online submission

- Rigorous peer review

- Open access: articles freely available online

- High visibility within the field

- Retaining the copyright to your article

Submit your next manuscript at springeropen.com 